\title{
DESIGN AND ANALYSIS PERFORMANCE ON 22 M SUBMARINE PROPELLERS
}

\section{DESAIN DAN ANALISA KINERJA PROPELLER KAPAL SELAM MINI 22 M}

\author{
Mahendra Indiaryanto $^{a}$, Taufiq A. Setyanto ${ }^{b}$, Nurwidhi Asrowibowo ${ }^{a}$, Navik Puryantini ${ }^{a}$ \\ a Laboratory for Hydrodynamics Technology \\ ${ }^{b}$ Center of Technology for Maritime Industrial Engineering \\ Agency for The Assessment and Application of Technology \\ Email : mahendra.indiaryanto@bppt.go.id
}

\begin{abstract}
Many methods approach in designing a propeller for a $22 \mathrm{~m}$ submarine, which is based on the literature of propeller design that has been widely publicized, specifically the type B-series propeller. From the B-series propeller design, it can be known that the performance diagram in the form of the propeller coefficient is finally correlated with the $22 \mathrm{~m}$ submarine resistance value that has been tested at BTH-BPPT. This study's objective is to produce a propeller design with good hydrodynamic aspects, especially propeller with high efficiency and cavitation phenomena that do not occur on the propeller. The implementation of this research can be done by modification on the skew angle on the B-series propeller. It is expected to choose the right B-series propeller and skew angle propeller modification, capable of providing high-efficiency values and loss of cavitation in the leaf area of the propeller. The production of propeller models is needed for conducting an open water test in the Towing Tank and the cavitation test in the cavitation tunnel at the Hydrodynamics Technology Center for the Agency for Assessment and Application of Technology (BTH - BPPT).
\end{abstract}

Key Word: Design; Propeller; Cavitation

\begin{abstract}
Abstrak
Beberapa metode pendekatan perancangan propeller untuk kapal selam 22 meter berdasarkan literatur telah dipublikasikan secara luas, terutama propeller tipe B Series. Penelitian ini bertujuan untuk menghasilkan sebuah rancangan propeller dengan aspek hidrodinamika yang baik, terutama propeller dengan efisiensi tinggi dan tidak ada kavitasi. Implementasi pada penelitian ini dengan melakukan modifikasi kemiringan sudut pada propeller tipe B-Series. Untuk memilih propeller tipe B-Series yang tepat dengan melakukan modifikasi kemiringan sudut, sehingga dihasilkan nilai efisiensi yang tinggi dan kurangnya kavitasi pada bagian daun pada propeller. Model propeller dibuat untuk pengujian di Towing Tank dan pengujian kavitasi dalam terowongan kavitasi Balai Teknologi Hidrodinamika - Badan Pengkajian dan Penerapan Teknologi (BTH-BPPT).
\end{abstract}

Kata Kunci : Desain; propeller; Kavitasi

Received : 20 July 2020, Revised : 07 August 2020, Accepted : 13 August 2020

Republic of Indonesia. The effort to maintain the sovereignty of the Republic of Indonesia

\section{INTRODUCTION}

Indonesia is a country that nearly two-thirds of its territory is the sea. Therefore the marine defense system is very important in maintaining the sovereignty of the is the independence of the supply of defense equipment, one of them is the provision of submarines $^{3}$. The important aspect of designing a submarine is the propulsion system or propeller ${ }^{9}$. This aspect is an important part related to the propulsion 
system as the main element of the hydrodynamic aspect ${ }^{8}$. Effective propulsion is needed for optimum submarine design ${ }^{2}$.

Submarine propellers must have low cavitation because high cavitation will accelerate the cavitation erosion process on the propeller blade ${ }^{1}$.

Propelller cavitation occurs because water fluid passes through the foil propeller, the flow on the side of the chamber foil will be faster than at the bottom of the foil 10. As the rotational speed of the propeller increases, the pressure on each foil that forms the propeller decreases. And there is a saturation process with the appearance of bubbles in the propeller disk area.

If the surface tension of the bubbles is lower than the pressure of the water fluid towards the propeller. Then, the bubbles will burst and the pressure of the bubbles presses on the foil area which forms the propeller blade10. The process of cavitation erosion on the propeller occurs in several parts.

- Tip cavitation

- Face cavitation

- Root cavitation

- Boss vortex cavitation

The erosion process on the propeller $n$ ". reduce the thrust on the propeller and resı in a decrease in propeller efficiency. addition to reducing efficiency, cavitation ( the propeller can also cause vibrations to th propeller when it is operated, due to th unbalanced propeller due to defects certain propeller areas.
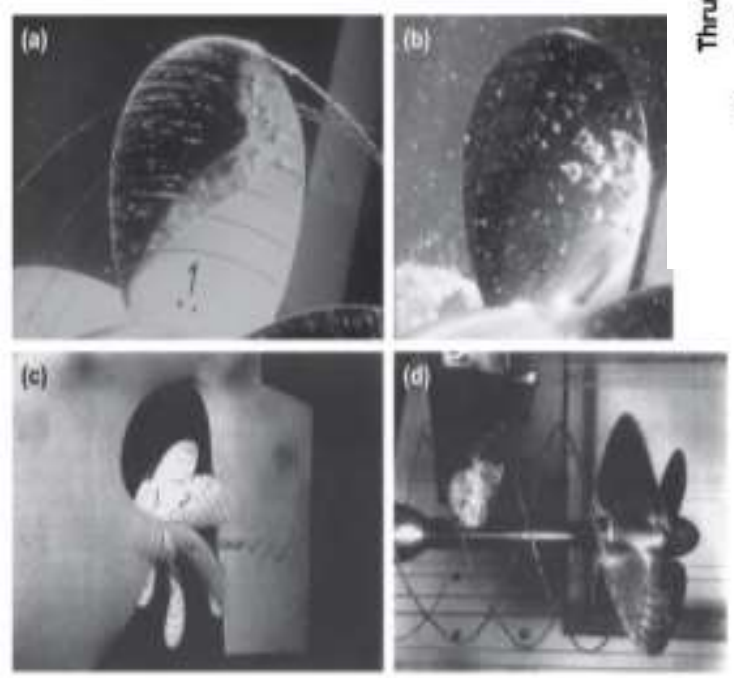

Figure 1.

Phenomenon of cavitation on the propeller $11^{9}$

As a continuation of these studies ${ }^{4,5}$, further research stages are needed. The purpose of this study is to produce a propeller design that meets the good hydrodynamic aspects with high efficiency and low cavitation.

\section{MATERIALS AND METHODS}

The data required in designing a Propeller is the $22 \mathrm{~m}$ submarine resistance testing data that have been implemented in the previous year. With the results table of the resistance test, the propeller thrust can be calculated using the equation:

$T=\frac{R}{1-t}$

Where.

$T=$ Propeller Thrust $(\mathrm{N})$

$R=22 \mathrm{~m}$ Mini Submarine Resistance $(\mathrm{N})$

$t=$ Thrust deduction factor

From these calculations, it can be predicted how much thrusts are needed to move the submarine at a specified velocity.

To predict the value of the thrust deduction factor can be seen at the following chart (Fig.2)

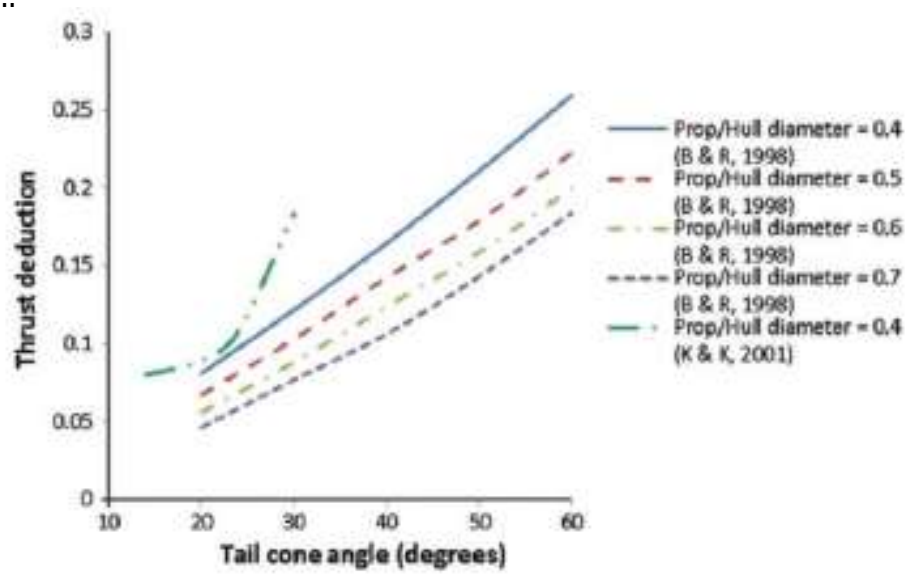

Figure 2.

Thrust deduction (adapted from Burcher and Rydill 1998, and Kormilitsin and Khalizev 2001) ${ }^{9}$

From the graph above, it can be seen that the value of the thrust deduction factor is based on the comparison of propeller diameter with submarine hull diameter and tail cone angle on the submarine stern.

From the graph above, the prediction of the propeller thrust deduction factor is 0.11 , where the angle of the Tail cone on the submarine hull stern model is $24 \mathrm{deg}$, and 
the ratio of propeller diameter/propeller diameter is 0.4 .

Fig. 3 is the picture of the $22 \mathrm{~m}$ minisubmarine hull model that was designed in the previous year with a 1:7 scale model.
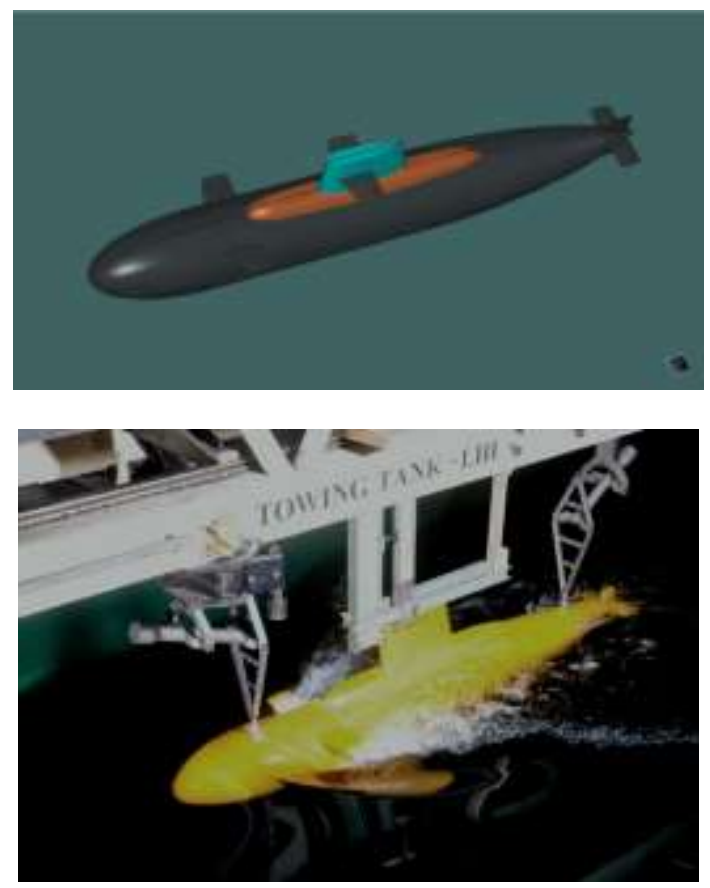

Figure 3.

3D model and mini-submarine model resistance test at Towing Tank BTH-BPPT

The testing of submarine models is carried out at speeds of 3-14 knots (in actual scale) or $0.583-2.722 \mathrm{~m} / \mathrm{s}$ (in model scale). From the test results of the $22 \mathrm{~m}$ minisubmarine model, the extrapolation process can be carried out to obtain the true resistance value.

Table 1.

Test result resistance of the mini-submarine model

\begin{tabular}{ccccc}
\hline VS & CFS & CTS & RS & PE \\
\hline Knots & $\left(10^{-5}\right)$ & $\left(10^{-5}\right)$ & $\mathrm{kN}$ & $\mathrm{kW}$ \\
3 & 244 & 2888 & 5.3 & 0.916 \\
4 & 233 & 3619 & 11.9 & 0.880 \\
5 & 225 & 4469 & 22.9 & 0.820 \\
6 & 219 & 5252 & 38.8 & 8.2 \\
7 & 214 & 5948 & 59.9 & 24.5 \\
8 & 210 & 7116 & 93.5 & 59 \\
9 & 207 & 9355 & 156 & 120 \\
10 & 203 & 8286 & 170 & 216 \\
11 & 201 & 5511 & 137 & 385 \\
12 & 198 & 4012 & 119 & 720 \\
13 & 196 & 3336 & 116 & 875 \\
14 & 194 & 3290 & 132 & 775 \\
\hline
\end{tabular}

$V s=$ mini submarine model Velocity $(\mathrm{m} / \mathrm{s})$

$n=$ Propeller Rotation $(\mathrm{rad} / \mathrm{sec})$

$D=$ Propeller diameter $(\mathrm{m})$

From this calculation, several coefficients have been designed, such as velocity, propeller diameter, and propeller rotation. As for the wake fraction factor, can be used the following graph Fig. 4.

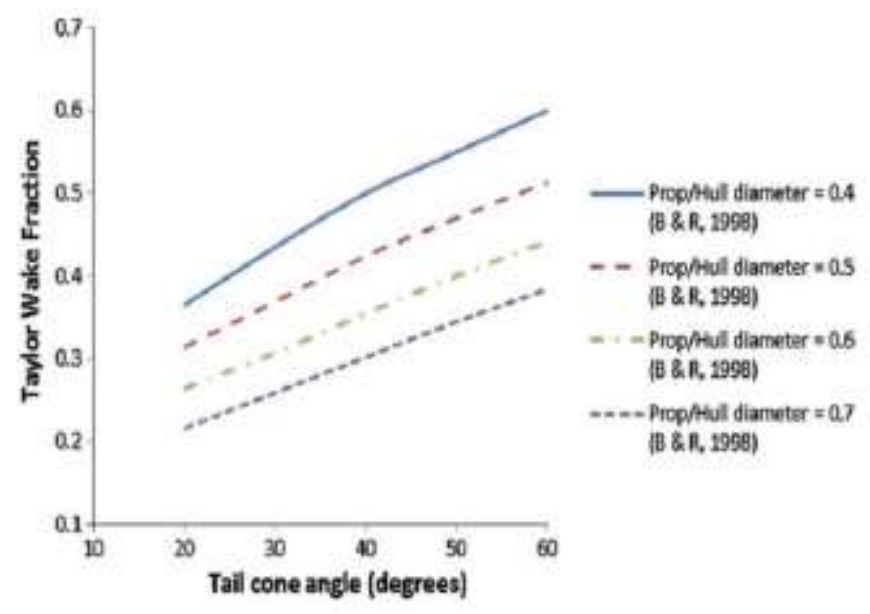

Figure 4.

Taylor wake fraction (adapted from Burcher and Rydill 1998) ${ }^{10}$

Same as the explanation in the first graph Fig. 2, where the value of the Taylor Wake Fraction Factor can be predicted by using a submarine hull dimension/propeller diameter comparison with the Tail Cone angle on the submarine stern hull.

Based on the in Fig. 4, it can be predicted that the value of the wake fraction factor of 0.4 , so by using Equation 2, the $w=$ Wake Fraction factor 
value of the Advanced Coefficient $(\mathrm{J})$ can be predicted, which is equal to 0.534 .

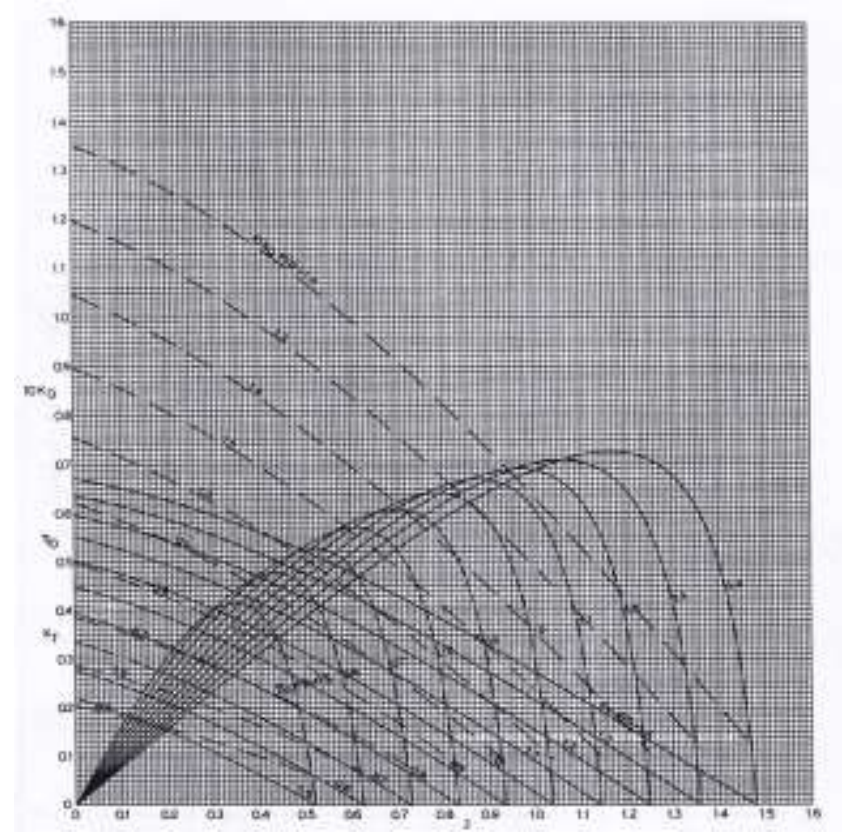

Figure 5.

Open water diagram of B-series type B7-1056

From the prediction value of Thrust propeller and Advance Coefficient propeller, several B-series propeller designs can be selected, which are suitable for integration of the $22 \mathrm{~m}$ submarine hull through the propeller modification process. Where for B-series propeller with seven blades and blade area ratio $(\mathrm{Ae} / \mathrm{Ao}$ ) 1.05, which is suitable for the $22 \mathrm{~m}$ mini-submarine hull type. and the following is a diagram of the B-series open water propeller diagram Fig.5.

From Figure 5, it can determine the value of the Thrust coefficient (KT), Torque coefficient (10KQ), and propeller efficiency (n) on the $\mathrm{Y}$-axis and the value of $\mathrm{J}$ (advances coefficient) on the $X$-axis which has been calculated by equation 2 .

Based on Figure 5, the KT coefficient value is $0.36,10 \mathrm{KQ}$ value is 0.575 , and the efficiency value is 0.532 using the following equation. The value of Thrust and Torque propeller B-series Type B7-105 can be obtained.

$$
\begin{aligned}
& K T=\frac{T}{\rho n^{2} D^{4}} \\
& K Q=\frac{Q}{\rho n^{2} D^{5}} \\
& \eta=\frac{K T J}{2 \pi K Q}
\end{aligned}
$$

Where.

$$
\begin{aligned}
& K T=\text { Thrust Coefficient } \\
& T=\text { Propeller thrust }(\mathrm{N}) \\
& K Q=\text { Torque Coefficient } \\
& Q=\text { Propeller Torque }(\mathrm{Nm}) \\
& \rho=\text { Density of water }\left(\mathrm{Kg} / \mathrm{m}^{3}\right) \\
& \eta=\text { Propeller Eficiency } \\
& n=\text { Propeller Rotation }(\mathrm{rad} / \mathrm{sec}) \\
& D=\text { Propeler Diameter }(\mathrm{m})
\end{aligned}
$$

After modification of the B-series propeller, to reduce the cavitation of the propeller, it is necessary to change the skew angle of the propeller tip. These changes will change the contour shape of the blade propeller. Figure 6 shows a working drawing for making the propeller model to be tested. 
Design And Analysis Performance On 22 M Submarine Propellers (Mahendra Indiaryanto, Taufiq A. Setyanto, Nurwidhi Asrowibowo, Navik Puryantini)

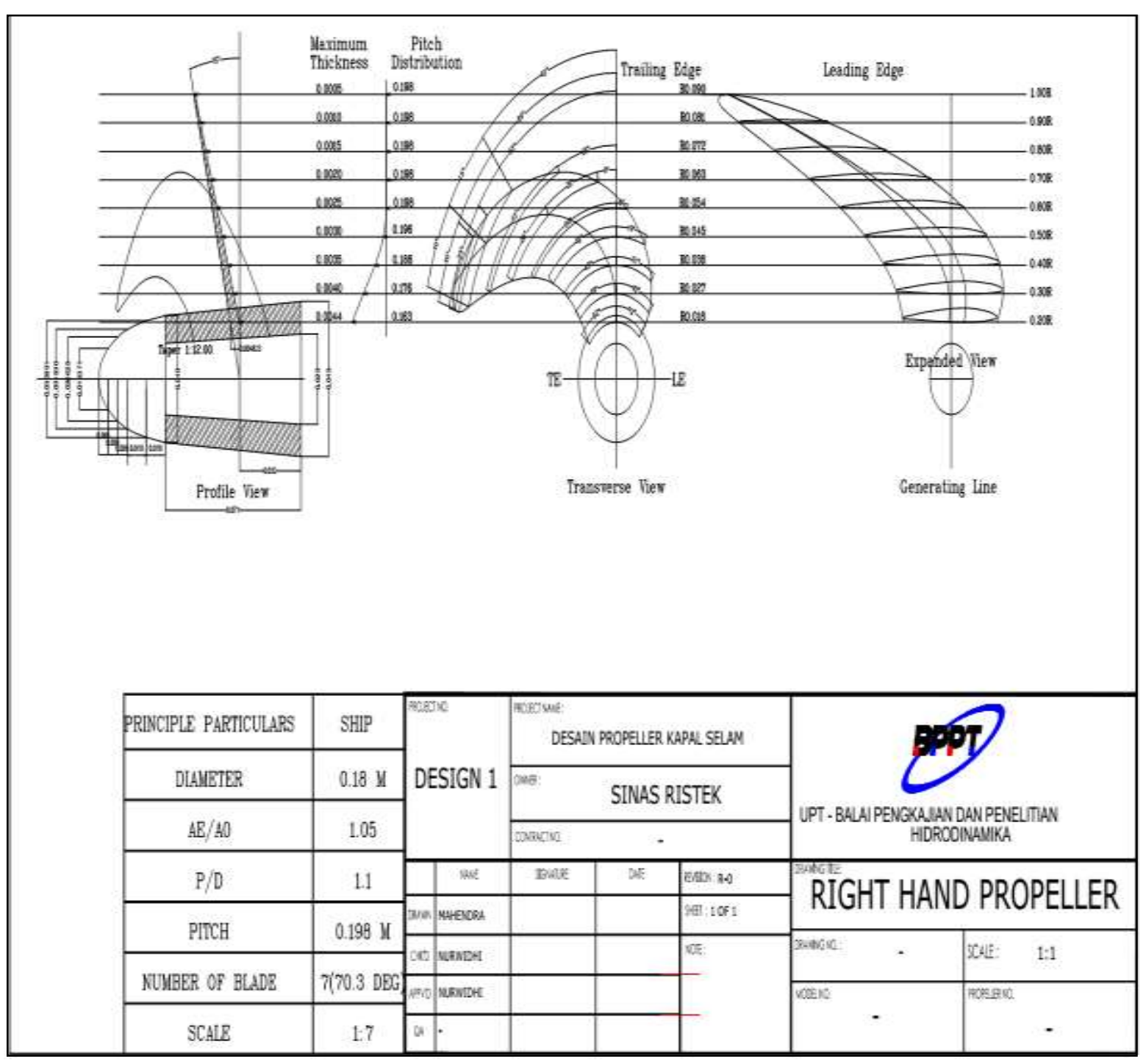

Figure 6.

B-series Propeller type B7-105 with skew angle changes

\section{RESEARCH METHOD}

From literature studies and propeller design calculations that have been explained based on theory to propeller model testing at Towing Tank and Cavitation Tunnel facilities is explained through Figure 7.

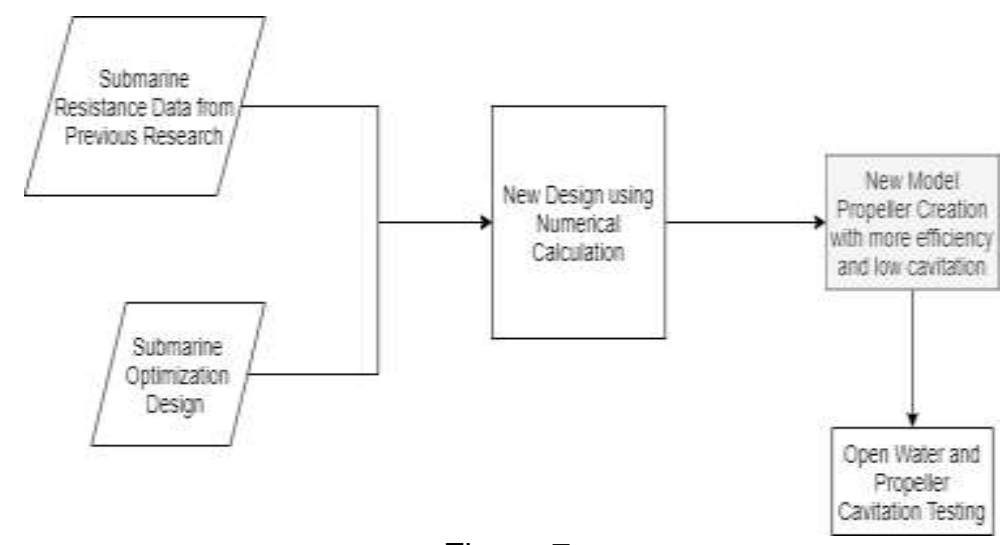

Figure 7.

Research Flowchart 
The flow of research in Figure 7 can be explained as follows:

- Conduct literature studies to obtain $22 \mathrm{~m}$ submarine resistance at each velocity and several other kinds of literature to obtain predictions of Thrust deduction factor and Taylor wake fraction

- Modified the new propeller design, according to the explanation in the basic sub-chapter of the theory and obtained the main dimension of the propeller.

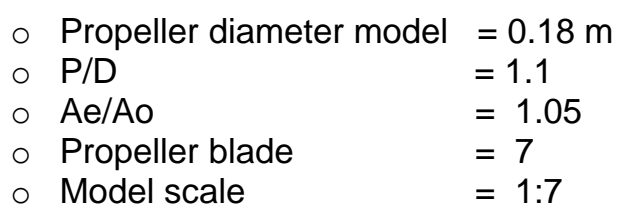

- Perform propeller models based on work drawings and propeller models, as seen in figure 8.

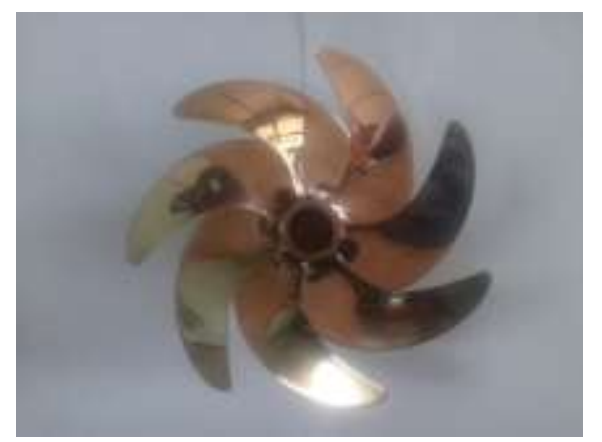

Figure 8.

B-series Model propeller type B7-105 with skew angle changes.

- The resulting propeller model will be tested on the Towing Tank to determine the characteristics of the propeller.

- It is testing the propeller model in the cavitation tunnel to determine whether there is cavitation that occurs in the propeller.

\section{RESULTS AND DISCUSSION}

From the results of numerical simulation calculations, the maximum efficiency value is 0.632 , which is equivalent to the value of the Thrust coefficient of 0.209 and Torque coefficient of 0.438 . From this value, the propeller can work efficiently at a value of $\mathrm{J} 0.831$.

From the data in Table 2, the characteristics of the propeller can be known. However, it cannot be guaranteed that the propeller numerical simulation as it represents the condition of the propeller when testing the model. Because there is a correction to the Dummy hub, which is a correction to the Torque propeller, and the vortex phenomenon does not appear in the hub section and propeller. But this simulation can be used as a starting point in propeller design selection so that it can be used as the basis for propeller design selection. For this, it is important to test the model to perform the performance of the proposed propeller.

Table 2.

Numerical simulation result

\begin{tabular}{cccc}
\hline $\mathbf{J}$ & $\mathbf{K T}$ & $\mathbf{1 0 K Q}$ & Efficiency \\
\hline 0.083 & 0.747 & 1.117 & 0.088 \\
0.166 & 0.717 & 1.078 & 0.176 \\
0.249 & 0.676 & 1.011 & 0.265 \\
0.332 & 0.611 & 0.928 & 0.349 \\
0.415 & 0.522 & 0.833 & 0.438 \\
0.499 & 0.459 & 0.740 & 0.493 \\
0.582 & 0.386 & 0.643 & 0.566 \\
0.748 & 0.267 & 0.511 & 0.621 \\
0.831 & 0.209 & 0.438 & 0.623 \\
0.914 & 0.147 & 0.345 & 0.621 \\
0.991 & 0.089 & 0.257 & 0.548 \\
1.080 & 0.028 & 0.147 & 0.324 \\
\hline
\end{tabular}

Based on the results of numerical simulations of Table 2, the propeller model was made at the Mechanical Workshop at BTH. And the Open Water Test was carried out so that the characteristics shape of the propeller are was designed. The test was carried out at a constant propeller rotation at a velocity of $13 \mathrm{Rps}$ with variations in the velocity of the carriage ranging from 0.194 $\mathrm{m} / \mathrm{s}$ to $2,528 \mathrm{~m} / \mathrm{s}$.

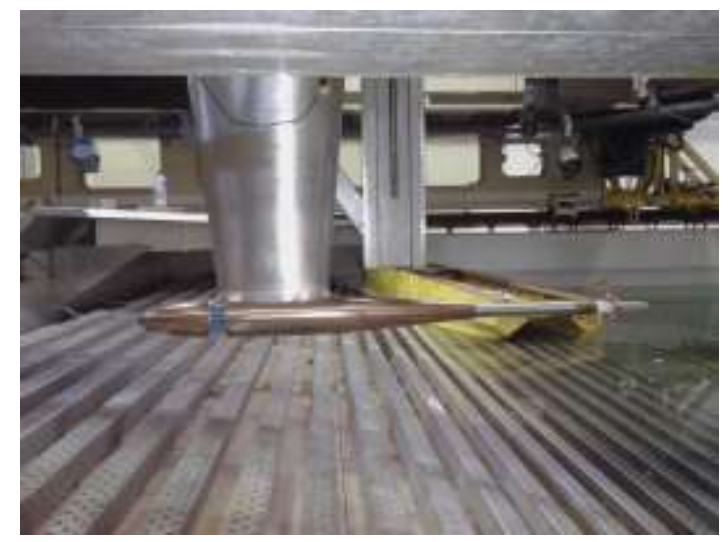

Figure 9.

Open water test of mini-submarine propeller models

The Open Water Test propeller model tests are carried out under Calm Water conditions in accordance with ITTC regulations. From the test results, it can be presented in the form of measurement data 
in table 3, where it appears that the Thrust value of the Propeller model is able to drive the mini-submarine model from the previous research. So the thrust generated by the propeller is capable of running a minisubmarine model at every velocity variation. From the results of the propeller model test in Table 3, it is known that the maximum efficiency value is 0.644 , where the value is directly proportional to the Thrust coefficient of 0.176 and the Torque coefficient of 0.358 . So from the results of this test, it is known that the propeller can work efficiently at an advanced coefficient value (J) 0.824. By testing the propeller model, the characteristics of the propeller model can be known to be true.

Table 3

Open water propeller model test results

\begin{tabular}{cccc}
\hline $\mathbf{J}$ & $\mathbf{K T}$ & $\mathbf{1 0 K Q}$ & Efficiency \\
\hline 0.082 & 0.557 & 0.916 & 0.080 \\
0.164 & 0.539 & 0.880 & 0.160 \\
0.246 & 0.502 & 0.820 & 0.240 \\
0.327 & 0.458 & 0.750 & 0.318 \\
0.412 & 0.405 & 0.681 & 0.390 \\
\hline
\end{tabular}

\begin{tabular}{cccc}
\hline $\mathbf{J}$ & $\mathbf{K T}$ & $\mathbf{1 0 K Q}$ & Efficiency \\
\hline 0.495 & 0.358 & 0.607 & 0.465 \\
0.660 & 0.261 & 0.474 & 0.580 \\
0.745 & 0.220 & 0.422 & 0.619 \\
0.842 & 0.176 & 0.358 & 0.644 \\
0.907 & 0.125 & 0.283 & 0.639 \\
0.99 & 0.082 & 0.212 & 0.614 \\
1.074 & 0.023 & 0.121 & 0.322 \\
\hline
\end{tabular}

From both tables, it can be seen that from numerical calculations and model tests obtained approximately the same characteristics where the maximum efficiency ranges from 0.6 and ranges from $\mathrm{J}$ to 0.8. So that numerical simulations that have been performed can be used as an initial reference to find out the performance of the propeller that has been designed before testing the Propeller models.

From table 2 and table 3, we can present a graph of performance diagrams between the test model and numerical simulation, which can be seen in Figure 9 . It can be compared between numerical simulations and model tests that can be presented as follows.

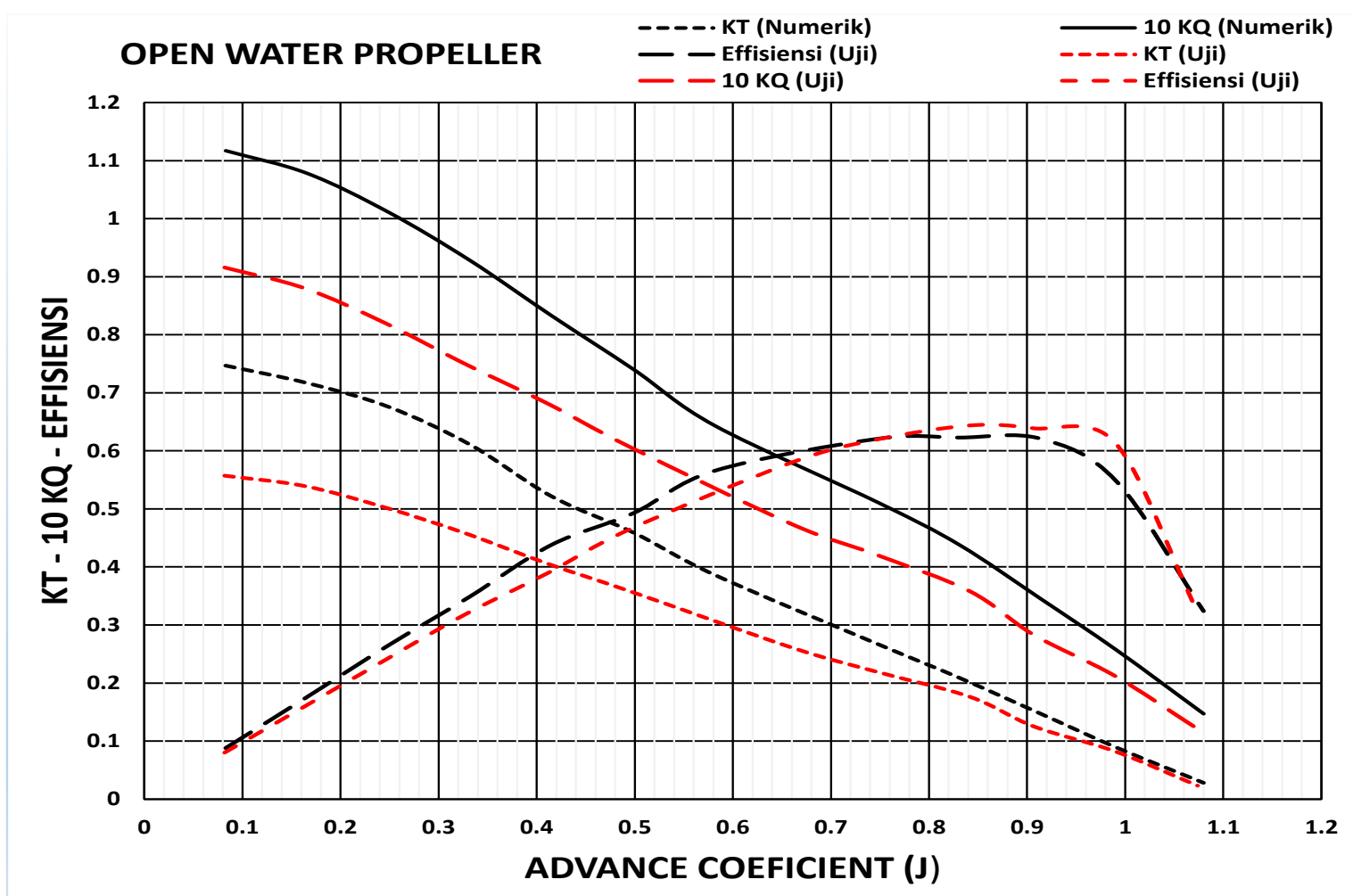

Figure 10.

Comparison of Open Water diagrams from propeller numerical simulation results and propeller model tests

Furthermore, after knowing the performance of the B-series propeller, which has changed its skew angle, the propeller design match can be recalculated when the submarine runs at 8 knots in the water. Or 
when the value of the advance coefficient $(\mathrm{J})$ is 0.534 .

From the interpolation results in a value of the advance coefficient value $(\mathrm{J})$ at a point of 0.534 , a Thrust coefficient value of 0.335 while Torque coefficient ( $10 \mathrm{KQ}$ ) of 0.576 . Of these two coefficients, it can be found the propeller efficiency value of 0.495 using equation 5 . From these results can be seen the decrease in efficiency from 0.532 to 0.495 . This result caused by a decrease in propeller thrust due to changes in the contour of the propeller blade. But back to the original intention, that skew angle propeller is needed to minimize cavitation in the tip propeller area.

After the characteristics of the propeller model are known from the open water test, it is important to consider the cavitation problem of the propeller model. For results of cavitation can be presented in table Table 4.

Table 4.

Tunnel cavitation test results

\begin{tabular}{ccccc}
$\begin{array}{c}\text { Flow } \\
\begin{array}{c}\text { Speed } \\
(\mathrm{m} / \mathrm{s})\end{array}\end{array}$ & $\begin{array}{c}\text { Propeller } \\
\text { Rotation } \\
(\mathrm{Hz})\end{array}$ & $\begin{array}{c}\text { Press } \\
1 \text { (bar) }\end{array}$ & $\begin{array}{c}\text { Press } \\
1.4 \\
(\text { bar })\end{array}$ & $\begin{array}{c}\text { Press } \\
1.8 \\
(\text { bar })\end{array}$ \\
\hline 1.8 & 13 & $\mathrm{Nc}$ & $\mathrm{Nc}$ & $\mathrm{Nc}$ \\
1.9 & 13 & $\mathrm{Nc}$ & $\mathrm{Nc}$ & $\mathrm{Nc}$ \\
2.0 & 13 & $\mathrm{Nc}$ & $\mathrm{Nc}$ & $\mathrm{Nc}$ \\
2.2 & 13 & $\mathrm{Nc}$ & $\mathrm{Nc}$ & $\mathrm{Nc}$ \\
2.5 & 13 & $\mathrm{Nc}$ & $\mathrm{Nc}$ & $\mathrm{Nc}$ \\
2.5 & 20 & $\mathrm{Hc}$ & $\mathrm{Hc}$ & $\mathrm{Hc}$ \\
2.5 & 30 & $\mathrm{Hc}$ & $\mathrm{Hc}$ & $\mathrm{Hc}$ \\
2.5 & 33 & $\mathrm{Hc}$ & $\mathrm{Hc}$ & $\mathrm{Hc}$ \\
\hline
\end{tabular}

Where.

$$
\begin{array}{ll}
\mathrm{Hc} & =\text { Hub Cavitation } \\
\mathrm{C} & =\text { Cavitation } \\
\mathrm{Nc} & =\text { No Cavitation }
\end{array}
$$

From Table 4, it can be seen that with each variation inflow velocity, and propeller rotation at $13 \mathrm{~Hz}$ and variations in pressure almost do not occur cavitation or low cavitation. While the hub cavitation will only occur if the propeller rotates at 20,30 , and $33 \mathrm{~Hz}$. For this to eliminate cavitation on the hub, it is necessary for the Vin design, which will be installed on the propeller cap. So, in addition to eliminating cavitation at the propeller hub, the function of Vin is able to reduce torque due to the loss of vortex in the hub area. And the reduced torque of the propeller affects the increase in propeller efficiency values. The phenomenon of cavitation in the propeller model during the cavitation test can be seen in Figure 11.

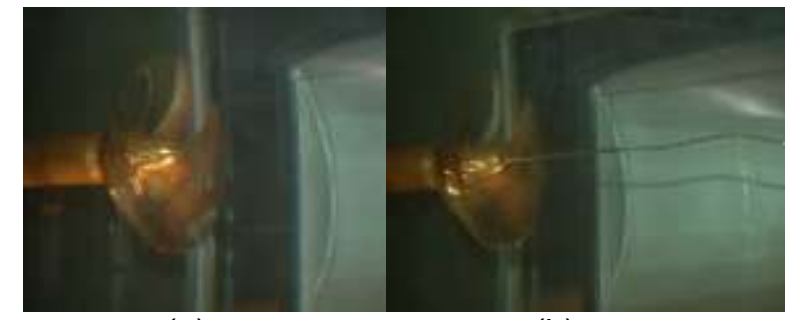

(a)

(b)

Figure 11.

The phenomenon of cavitation in propeller models.

\section{CONCLUSION}

From the results of propeller model testing and the numerical simulation results, it is obtained the maximum efficiency in the range of values 0.6 , regardless of the difference in the value of the Thrust propeller. Where the maximum efficiency value is in the range of Advance Coefficient (J) 0.8 There is a reduction in propeller efficiency occurs at the submarine operational point, from 0.532 to 0.495 . It is a result of changes in the shape of the propeller blade with the addition of skew angle. However, changes in the propeller blade need to be done with the aim of minimizing the propeller cavitation in the tip area. This can be proved by the cavitation test, wherein every variation of propeller rotation the cavitation phenomenon in the tip propeller area almost nonexistent. Only the cavitation hub can be reduced by vin design on the propeller cap. For the cavitation hub phenomenon to occur when the propeller is rotated above the operational submarine rotation of $20 \mathrm{rps}, 30 \mathrm{rps}$, and $33 \mathrm{rps}$.

\section{ACKNOWLEDGEMENT}

Ministry of Research, Technology and Higher Education (Ristekdikti) which has funded this research through the national innovation system (INSINAS) incentive scheme for the 2014 fiscal year

\section{REFERENCE $\left[\mathrm{MS}_{1]} \mathbf{S}\right.$}

1. Agung Purwana, Wisnu Wardhana, I Made Ariana, Dhimas Widhi $\mathrm{H}$, Numerical Study on Cavitation Noise of Symmetrical Blade Submarine Propeller, Proceeding pf Marine Safety and Maritime Installation MSMI, 2018

2. A. Vrijdag, D Stapersma dan T Van Terwisga, Control of Propeller Cavitation in Operational Conditions, 
Journal of Marine Engineering and Technology No. A16, 2010

3. Cahya Kusuma, I Made Ariana, Studi Numerik Modifikasi Propeller Kapal Selam 29 meter dengan Menggunakan High Skew, Rekayasa Energi Manufaktur Jurnal Vol 2 No 1, 2017

4. Endang Widjiati, Erwandi, Endah Suwarni, M Nasir, Nurwidhi Asrowibowo, Totok Sudarto, Yuniati. Rancang Bangun dan Uji Akustik Propeller Untuk Kapal Selam Mini, Prosiding InSINAS Kemenristekdikti, 2012.

5. Erwandi, Marx Jefferson, Cahyadi Sugeng JM, Dwi Wahyudi, Nurwidhi Asrowibowo, Desain dan Uji Hidrodinamika Kapal Selam Mini Berbobot 133 Ton, Prosiding InSINAS Kemenristekdikti, 2012.

6. G.Kuiper , The Wageningen Propeller Series. MARIN Publication 92-001, Wageningen Natherland, 1992.
7. Insanu Abdilla Cendekia Akbar, Deddy Chrismianto, Parlindungan Manik, Analisa Perbandingan Propeller Kapal Selam Mini Tipe B-Series dan AunOutlne Gawn Series Pada Kapal Selam Midget Type $150 \quad M$ Untuk Mengoptimalkan Kinerja Kapal Selam Dengan Metode CFD, Jurnal Teknik Perkapalan Vol. 3, No. 4 Oktober, 2015.

8. J. Carlton, Marine Propellers and Propulsion, 2nd ed. Oxford, UK (Butterworth- Heinemann), 2007.

9. J. Carlton, Marine Propellers and Propulsion, 3nd ed. Oxford, UK (Butterworth- Heinemann), 2013.

10. Kormilitsin YN, Khalizev OA Theory of Submarine Design. Saint Petersburg State Maritime Technical University, Russia. 2001.

11. Molland, Ship Resistance and Propulsion, 2011. 